\title{
Human rights and neo-liberal education in post-apartheid South Africa
}

\section{Thokozani Mathebula}

Wits School of Education, University of the Witwatersrand

Email: Thokozani.Mathebula@wits.ac.za

(Received 4 January 2018; accepted 7 May 2018)

\begin{abstract}
Internationally, people have different concepts of human rights. In this article, I discuss three dominant schools of thought through which human rights have been conceived of. These are the natural school (human rights as given), the deliberative school (human rights as agreed upon) and the protest school (human rights as fought for). I show that the thinking of deliberative scholars forms the basis of Rawls's (1971) principles of the social contract reflected in global, regional, and domestic human rights frameworks. I argue that the neo-liberal state (and, by implication, the neoliberal education agenda) in post-apartheid South Africa does not guarantee equal access to education as agreed upon during the political negotiation period in South Africa. Echoing the tenets of the protest school of thought, I maintain that, despite the anti-apartheid struggle movement's achievements in human rights, the right to education is yet to be fully realised. I employ two basic questions of political philosophy to support the protest scholars' call for continual struggle by (or for) those denied the right to education in post-apartheid, neo-liberal South African schools.
\end{abstract}

\section{Introduction}

We live in this world at a juncture where [neoliberal] global ${ }^{1}$ [isation] has shown that many of humanity's great achievements in human rights in recent centuries have begun to be eliminated. (Torres, 2009, p. 5)

... post-apartheid education ... (re)normalises the (ex)clusions of [many] within neoliberal capitalist human rights framework(s). (Becker \& du Preez, 2016, p. 55)

South Africa's anti-apartheid struggles that gave rise to [human rights] are now out of view. [Human] rights are fought for, won, lost, and won again. (Christie, 2010, p. 6)

1 Davids (2016) defines globalisation as the extension and intensification of worldwide social and economic relations. However, the focus of this article is on neoliberalism, a term that refers to the global economic system that emerged in the 1980s and 1990s. 
It is clear that neo-liberalism is the "new demon" (Torres, 2009, p. 2) of modern-day societies. In terms of education, the neo-liberal human rights framework undermines Gutmann's (1987) principle of non-repression by not granting all educable children the right to education in South Africa. I submit that the right to free, equal, and democratic education is also being eroded in post-apartheid South Africa. It is therefore reasonable to say that opposition to the neo-liberal state ${ }^{2}$ and its education agenda should be the main focus of the supposedly new struggle in post-apartheid South Africa. I

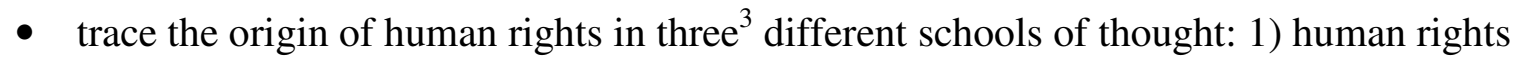
as entitlements based on nature; 2) human rights as existing through the social agreement; and 3) human rights as struggles waged "by or on behalf of the poor, the unprivileged and the oppressed" (Dembour, 2010, p. 3);

- show that through the principles of the social contract, human rights become the foundation of modern constitutional democratic states;

- argue that neo-liberal state ideology, governance, and policies sit uneasily with the right to education envisaged in the human rights framework in South Africa; and

- advocate for protest scholars' continual struggle by (or for) those denied the right to education in post-apartheid neo-liberal South African schools.

\section{Ontology of human rights: Schools of thought}

Dembour (2010) maintains that natural scholars conceive of human rights as given. Most importantly, the natural scholars accept that human rights entitlements are based on "nature, a short-cut which stands for God" and that "the universality [of these rights] derive from their natural character" (pp. 2-3). The state of nature, says Locke, is first a state of perfect freedom where a human being

possesses strength and reason, capable of providing own support and preservation, and govern his [sic] actions according to the dictates of the Law of Reason which God had implanted in him [sic]. It is evident that all human beings [are] born indiscriminately with all the same natural advantages and faculties-are equal amongst themselves. Second, a state of equality in which power and authority is reciprocal- $[$ with] no relationship of subordination or subjection unless God (the lord and master of them all) had clearly set one person above another and conferred on him an undoubted right to dominion and sovereignty. (1689/1960, pp. 304-305)

\footnotetext{
2 Raphael (1990) defines the state as "an association that maintains order and security, exercises universal jurisdiction backed by force and has sovereign authority" (1990, p. 55). As far as can be judged, the state has power to prevent harm to existing human rights (negative freedom) or promote the welfare (positive freedom) of its citizens. Sadly, in neo-liberal states, individual freedoms are guaranteed by freedom of the market economy and free trade.

Dembour (2010) identifies four schools of thought on human rights, i.e. natural scholars, deliberative scholars, protest scholars, and discourse scholars (human rights as talked about). I argue that because of the "lack of faith in human rights" the discourse school of thought is "the least prevalent . . . among human rights academics" (2010, p. 19). It is against this background that my historical exploration of what human rights are focuses mainly on the three major schools of thought.
} 
Locke's (1689/1960) ontological claim above supports the natural scholars' argument that individuals do not possess rights; rights flow from nature or God. Human beings govern their actions according to the dictates of the law pronounced by God and there is a link between the natural law and a "rational plan of nature established by God" (Horsthemke, 2016, p. 327). Smit (2013) agrees that "natural law states that rights flow from nature or God" (p. 49). But Horsthemke (2016) raises problems and objections against natural law that claims that whatever is natural is good or moral. First, Horsthemke maintains that the natural law "is not only logically deficient but it conflates facts and values." Second, after all "what is or is not natural or unnatural is the subject of considerable debate." Third, "natural law is not supported by the world view of modern science." Fourth, natural law "errs in building rationality, values, and purposiveness into the natural order of things" (p. 327). It is no surprise, therefore, that what was known as the natural school shifted towards the deliberative school of thought.

As their starting point, the deliberative scholars maintain that rights do not flow from nature or God; "human rights are political values that societies choose to adopt" Dembour (2010, p. $3)$. Similar to Grotius's (1620/2005) assertion that human right(s) are in the possession of individuals, deliberative scholars discard the natural scholars' ontology of human rights. Deliberative scholars argue that individuals have intrinsic "natural power to right [themselves]" (p. 157). As we shall see in the next section, at the heart of Sartre's transphenomentality of being "the law of being of the for-itself, is the ontology foundation of consciousness" (1974, p. 53). As Berlin argues, a "positive sense of the word liberty derives from the wish on the part of the individual to be his own master" (1969, p. 131). As a consequence, Kant (1785/1969) locates the basis of rights not in nature, but in the rational capacities of autonomous human beings. For Kelly et al., people "abandon the state of nature and submit to external public and lawful coercion" (2013, p. 127) that can rule society. The rational nature of humans as free, intelligent, self-directing beings enables them to establish absolute laws applicable to humanity. By applying our reason, all rational agents ask themselves the following questions:

- What would happen if we universalise absolute law?

- What rule (or maxim) would we be following if we were to universalise absolutism?

- Would we be willing for that supreme rule to be followed by everyone all the time?

If the deliberative scholars' argument is accepted, human rights emerge from a societal agreement that "govern[s] the assignment of rights and duties and regulate[s] the distribution of social and economic advantage" (Rawls, 1971, p. 61) as I will show later in this article.

As already stated, the protest scholars view human rights as a struggle waged on behalf of those denied the basic rights, privileges, and benefits of citizenship. In line with the position of the protest scholars, Dembour maintains that they 
look at human rights as claims and aspirations ... in favour of the oppressed . . they advocate relentlessly fighting for human rights, as one victory never signals the end of all injustice ... most of them are more concerned with concrete source of human rights in social struggles, which are as necessary as they are perennial. (2010, p. 3)

There are four points worth noting about the concept of human rights as held by protest scholars. First, the protest school accepts that human beings are rights holders; human rights are a call to ensure that the basic rights of fellow citizens are respected and protected. Second, protest scholars maintain that human rights injustices (and abuses) bring about an endless demand for, or need of, redress in societies. Third, the inability of human rights institutions to realise justiciable rights is the source of perennial struggle to give actual form to the ideal. Fourth, the protest scholars' call for a "return to true human rights" (Dembour, 2010, p. 9) is a perpetual fight for the realisation of human rights for the oppressed, in particular. It may be added that at times human rights become the site of struggle for recognition even if this means death. For example, this struggle inspired the Haitian Revolution in 1791 that ushered in black independence to the former French colony; led to the abolition of the French monarchy and the execution of King Louis XVI in 1793; and propelled Nelson Mandela to fight for a free, equal, and democratic society even if it meant that protesters paid the ultimate penalty. Overall, the historical exploration of human rights can be summarised as follows: natural law is the law according to the will of God; human rights are attributed to a rational, consensus-oriented deliberative discourse; and human rights are a life and death struggle for many.

\section{Social contract: Human rights framework}

As noted above, Locke (1689/1960) maintained that the state of nature is first a state of perfect freedom, i.e. human beings are free, equal, and independent of any social order. Second, the state of nature is a state of equality in which "power and authority is reciprocal [with] no relationship of subordination" (p. 304). In stark contrast, Hobbes's (1651/1985) state of nature is one of "war of every man against man." To put it bluntly, in the state of nature, men compete for survival, safety and glory, and in the process "life [becomes] solitary, poor, nasty, brutish, and short" (p. 185). To escape the natural condition, Hobbes (1651/1985) employed the device of the social contract, "the mutual transferring of right ... which men call contract" (p. 192). As social creatures, "one of the main reasons human beings would be willing to enter into a social contract and submit to being ruled by a government" is that government regulates "disagreements and conflicts in a neutral way" (Kelly et al., 2013, p. 106). With this insight, Rawls (1971) argues that the social contract becomes just if two principles of justice are chosen:

Each person is to have an equal right to the most extensive basic liberty compatible with similar liberty for others. 
Social and economic inequalities are to be arranged so that they are both (a) reasonably expected to be to everyone's advantage, and (b) attached to positions and offices open to all. (p. 60)

There are three points worth noting about Rawls's (1971) social contract theory. It defines and secures equal liberties of citizenship, that is, rights and duties (the liberty principle); the distribution of wealth and income in society should be equal (the difference principle); and political positions (or authority) should be accessible to all (the fair opportunity principle). From a perspective of political philosophy, ${ }^{4}$ there is a general presumption (by those in positions of authority) in favour of an equal distribution of goods among all citizens. To sum up, social contract theory states that human beings "living together according to reason, without a common superior on earth, with authority to judge between them" is the state of nature" (Locke, 1689/1960, p. 304). The primary purpose of government is to protect natural rights. " $[\mathrm{M}] \mathrm{an}$ 's [sic] right is laid aside, either by simply Renouncing it; by Transferring it to another ... And when a man has ... abandoned or granted away his Right; then he is ... OBLIGED or Bound ... and it is his DUTY, not to make voyd that voluntary act of his own" (Hobbes, 1651/1985, p. 191). On the whole, "the social contract is based on a coalition of the wills of all private individuals in a nation" (Scruton, 2007, p. 365). If we agree to be governed, we must rationally consent to obey every law the government passes. It is not surprising, therefore, that human rights are firmly rooted in a democratic state with the power to protect and promote them.

The Universal Declaration of Human Rights (United Nations, 1948) proclaims that "[a]ll human beings are born free and equal in dignity and rights . . endowed with reason" (p. 1). The United Nations Convention on the Rights of the Child (United Nations, 1989) pledges to provide, as well as enforce, the development of respect for human rights and fundamental freedoms, and the principles enshrined in the Charter of the United Nations. The African Charter on Human Rights and People's Rights (Organisation of African Union, 1986) "recognise[s] that the fundamental rights stem from the attributes of human beings, which justifies their national and international protection . . . that the reality and respect of people's rights should necessarily guarantee human rights" (p. 1). The Constitution of the Republic of South Africa (Republic of South Africa, 1996) establishes a society based on democratic values, social justice, and fundamental human rights. The rights protected in the South African Bill of Rights (Republic of South Africa, 1996) include, inter alia,

- First-generation rights: civil and political rights, i.e. rights and freedoms that prohibit the state from interfering in the affairs of the individual;

- Second-generation rights: economic and social rights, i.e. rights concerned with the state's obligation to provide and improve socio-economic conditions of the individual; and

$4 \quad$ According to Runes (1960) political philosophy is the branch of philosophy that deals with political life, namely, the relationship of individuals and communities to the state. For Wolff (1996), there are only two questions in political philosophy: Who gets what? and Says who? The first of these questions is about the distribution of citizens' rights, for example, the right to education. The second question concerns political power, that is, it is about rulers who hold power to distribute citizens' rights, such as the right to education. 
- Third-generation rights (or group or solidarity rights), namely, rights that are people centred rather than individual-centred.

My focus is on the second-generation rights, one of which is the right to basic education. The United Nations Declaration of Human Rights (United Nations, 1948) claims that "everyone has a right to education [that] shall be directed to the full development of the human personality and to the strengthening of respect for human rights and fundamental freedoms" (p. 4). The African Charter on the Rights and Welfare of the Child (Organisation of African Unity, 1999) states that the education of the child must be directed to "fostering respect for human rights and fundamental freedoms" (p. 4). In addition to safeguarding fundamental human rights, the Constitution of the Republic of South Africa (1996) also promises the right to basic and adult education in South Africa. The South African Schools Act (Department of Education, 1996) aims to uphold the rights of all learners. Against this backdrop, the Curriculum and Assessment Policy Statement (CAPS) (Department of Education, 2012) promotes "human rights, inclusivity [and] social justice as defined in the Constitution of the Republic of South Africa" (p. 5).

I question whether the post-apartheid South African human rights framework translates into the reality of people's lived experiences. In Christie's (2010) words,

the gap between the expression of rights and their delivery in practice has haunted [the] existence [of a human rights framework] . . [O]ne of the major shortcomings of formal statements of rights is that when they encounter the texture of lived experience, they easily prove to be abstract and empty. [T] here are dangers in not recognising the limited nature of rights. (p. 5)

There are a few points worth noting about Christie's (2010) analysis of the formal concept of human rights posited by deliberative scholars. She warns us of justiciable human rights that, according to Liebenberg (2010) "are abstracted from their social context and the real-world consequences flowing from the enforcement of these abstract rules" (p. 44). In relation to this, Hulme and Hulme (2012) remind us of the "ahistorical and de-personalised accounts of [human rights frameworks] complete[ly] devoid of human experiences" (p. 44). Waghid (2005) also cautioned us against formal human rights declarations, charters, and bills of rights that are unlikely to "create space[s] in which ... [political authorities] are able to break with what is supposedly fixed and finished and awaken us to the multiple voices and multiple realities" (p. 337).

As Prinsloo (2003) puts it, an international and national human rights framework must be "useable and useful within a particular context, and which concerns that context" (p. 61). This notion can be thought of as personal relevance. Viewed in this way, personal relevance has its origin in Sartre's (1974), transphenomenality of being, i.e. being for-itself whose "destiny is infinite . . . a fullness" (p. 50) "... the form of presence to itself" (p. 53). The disjuncture between a human rights framework and citizens' lived experiences raises the following questions: First, should social and economic rights (especially the right to education) be classified as human rights? After all, the right to education is often promoted 
through reasonable means and is not easy to enforce, whereas civil and political rights, i.e. the rights and freedoms which prohibit authorities from interfering in the affairs of the individual (like life) are easy to enforce. Second, if the second-generation rights are hardly protected by law, as protest scholars suggest, what is the point of listing them as human rights? Third, given this disconnect between the ideal (human rights framework) and the reality (achieving human rights), is it possible to protect and guarantee the right education in the face of neo-liberalism?

\section{The neo-liberal state agenda in education: Trends and debates}

Harvey defines neo-liberalism as "a theory of political economic practices that proposes that human well-being can best be advanced by liberating individual entrepreneurial freedoms within an institutional framework" (2007, p. 2). Steger and Roy (2010) add that neoliberalism is committed to "human rights as a springboard for a market-oriented society that glorifies individual self-interest, economic efficiency, and unbridled competition" (2010, p. $\mathrm{x})$. As I will go on to show, Steger and Roy also conceptualise neo-liberalism in three intertwined dimensions: (1) an ideology; (2) a mode of governance; and (3) a policy package.

- Neo-liberal ideology codifiers are a global power elite, managers and executives of large transnational corporations, corporate lobbyists, influential journalists and publicrelations specialists, intellectuals writing for a large public audience, celebrities and top entertainers, state bureaucrats, and politicians. (p. 11)

- Neo-liberal governmentality is rooted in entrepreneurial values such as competitiveness, self-interest, and decentralization. (p. 12)

- Educationally speaking, neo-liberal public policies are expressed in the D-L-P Formula: (1) deregulation (rolling back State control of the education system); (2) liberalisation (individual education is a springboard for a market-oriented society); and (3) privatisation (individuals buy and institutions sell education).

Steger and Roy's neo-liberal dimensions are reflected in post-apartheid South Africa. Mensah (2008) maintained that "the ideology of neo-liberalism seeks to expand global capital accumulation through free-trade, financial deregulation, privatization . . . spearheaded by the World Bank (WB), International Monetary Fund (IMF), World Trade Organisation (WTO)" (p. 1). Bassett (2008) asserted that when the ANC-led government came into power, it embarked on neo-liberal restructuring; in doing this it "called for a minimal state that permitted (international) market allocation of resources and setting of prices (p. 222) . . lower[ed] government spending (p. 222) [and] cut corporate taxes" (p. 226). As Hanson and Hentz (1999) put it, the ANC government's "move to neoliberal orthodoxy had implications for South Africa's budgets" (p. 496) ... "budgets [were] 'depoliticised' [and] remov[ed] from the realm of public debate and plac[ed] into the hands of economists and technocrats" (Bassett, 2008, pp. 222-223). 
According to Harris (1997), a neo-liberal agenda has shaped global education system(s), education discourse, education budgets, formal and hidden curricula, and educational relations. First, schools are viewed as "units of production whose performance is regulated by the mechanism of consumer choice based on the information about their relative effectiveness and efficiency" (p. 59). Second, writing about South Africa, Chisholm and Fuller (1996) argued that earlier talk of people's education and robust community participation g[ave] way to a technocratic discourse that "has relieved the Right and bewildered the Left" (p. 693). Third, Chisholm and Fuller also asserted that "education budgets are now justified in human capital terms, depoliticised and less frequently linked to participatory aims" (p. 697). Fourth, business interests in schools seem to drive the curriculum through "upskilling, life-long learning and transferable skills" (Phillips, 1998, cited in Allais, 2014, p. 58). Last, the rights and responsibilities of communities, parents, parents and learners, and other social groups with an interest in education are "defined as those of consumers of the products of education rather than those of participants in education" (Harris, 1997, p. 59). Given this neo-liberal global education agenda, how has neoliberal ideology, governmentality, and public policies influenced education in post-apartheid South Africa, in particular?

As neoliberal ideology codifiers, the ANC political elites, in the words of Christie, "opted for a macroeconomic policy that severely curtailed social spending, including spending on education ... introduced a market-related system of fees [and] curtailed the rights of many poor children to education" (2010, p. 8). Put differently, neoliberal ideology insists on the primacy of markets over the right to education by arguing that the attainment of socioeconomic rights (human rights) depends on free-market economics-a neo-liberal definition of school governance. As a notable example, the idea of decentralisation of power to school governing bodies ${ }^{5}$ (SGBs) is tied to neoliberal governmentality. To elaborate on this point, Lewis and Motala argued that the establishment of the SGB as a vehicle for the decentralisation of power to schools "was an outcome of the macroeconomic policy shift and their global influences" (2004, p. 117). As such, the neo-liberal school governors take good governance to mean a "reinvented and efficient form of government in a market-oriented society." They exercise fiscal restraint, they identify new sources of funding, and take a new look at "how we do business" (Lewis \& Motala, 2004, p. 120).

In public schools run by school governing bodies the introduction of market-related systems of fees means that a form of structural inequality is built into the education system, thus "render[ing] abstract and largely meaningless the idea of education as a right" (Spreen \& Vally, 2006, p. 356). Although Teese and Polesel are not writing about South Africa, they argue that schools themselves have become part of structural inequalities with schools serving rich communities (fortified sites), on the one hand, and schools serving working class and poor communities (exposed sites), on the other hand" (2003, cited in Christie 2008, p. 177). This implies that neoliberal governmentality put markets before human rights and this

The South African Schools Act (1996) paved the way for democratically elected and representative School Governing Bodies. The governance of every public school is vested in its governing body. The SGB of an ordinary public school is comprised of a) parents of learners at the school; b) educators at the school; c) learners in the eighth grade or higher in the school; d) non-teaching staff; e) the principal, in his or her official capacity; and f) coopted members. 
reinforces structural inequalities in post-apartheid South Africa; schools serve elite groups attending private schools at one extreme, and a mass of poor individuals from public schools, at the other. I note that neo-liberal governmentality interprets learners' failure or success in society purely on their individual attributes (not socio-economic inequalities). If we look more closely, we can see that the neoliberal education agenda in post-apartheid South Africa is likely to deny millions their right to education.

Allais (2014) has discussed how, in post-apartheid South Africa, the neoliberal economic framework penetrated educational policy. The extract below is worth quoting for what it reveals about state support of entrepreneurial values in education.

Neo-liberalism represents a new modality of government predicated on interventions to create the organisational and subjective conditions for entrepreneurship - not only in terms of extending the 'enterprise model' to schools and so forth, but also in inciting individuals to become entrepreneurs themselves. (Hart, 2006, cited in Allais, 2014, p. 57)

Similar to Allais's (2014) assertion, Motala and Vally point out that "the value of education is not defined by human rights terms, but is reduced to the needs of economic growth" in postapartheid South Africa (p. 3). Consequently, neoliberal education policy in South Africa treats learners as investors (and customers) who buy education in order to increase their competitive edge. In the words of Enslin and Horsthemke, "neo-liberal conceptions of the learner as both an investment and a customer ... enable her to take her place as a competitive individual working for private profit ... [and] play her part in making the national economy more globally competitive than others" (2016, p. 184). I agree with Torres (2009) that the language deregulation, liberalisation, and privatisation of education is intended to "open [international] markets while simultaneously training more competent [learners] to compete in those international markets" (p. 12). Unfortunately, neoliberal public policies are prescriptive and dictatorial. The market is conceived of as an efficient way to ensure the provision of the right to basic education. Seeing education as "entrepreneurial, ferociously competitive, profit-making corporations" (Sewpaul, 2014, p. 247) presents a clear and present danger to human rights education in South Africa. Instead of liberating the human potential, the state's neoliberal education entrenches social inequalities.

\section{Human rights: A critique of neo-liberal education}

In the history of education in South Africa, the role of schooling "from the official pronouncements of the rulers was to serve the perceived wishes, hopes, interests, and fears of those who rule the country, and to serve the creation and maintenance of a particular economic order" (Van den Berg, 1987, p. 4). This was the basis of the struggle for the right to education.

- The student-slaves resisted colonial Christian schooling that prepared them for subordinate positions, by flight and hiding in caves (le Roux, 2016; Molteno, 1991); 
- The Dutch (religious) and British (industrial) colonial governments saw schooling as a device to 'domesticate' the natives, to instruct them in the Christian religion, and to train them to meet the economic needs of the British Empire (Christie, 1988);

- Apartheid Education "socialised black students to accept social relations of apartheid as natural, i.e. superiority of whites and inferiority of blacks." (Nkomo, 1990, p. 2)

Scruton's (2007) conciliatory idea of politics (the art of the possible) is likely to provide answers to the questions of political philosophy by emphasising the struggle for the equal right of all to education. It is no surprise, therefore, that the anti-apartheid struggle movement's concept of people's education became an alternative philosophy of education in the 1980s (Vally, 2007). At the National Education Co-ordinating Committee (NECC) conference in Durban in 1986, Zwelakhe Sisulu stated that "the NECC has opened the way for people's power to be developed in our struggle for a free, democratic, compulsory and non-racial education (p. 107) . . . [as] part of the struggle for a free, democratic South Africa" (Sisulu, 1986, p. 111). Soon after the advent of democracy in 1994, compulsory school attendance was introduced for all South African learners from Grade 1 to 9 (7-15 years).

Regrettably, despite the laudable emphasis of the NECC's promise to eliminate "norms of competition, individualism and stunted intellectual development" (NECC, 1985, cited in Nkomo, 1990, p. 425), the educational milieu was fraught with problems of "persistent inequality, inadequately trained teachers, poor infrastructure, lack of educational materials, poor support and management, unmotivated learners, and low educational outcomes" (Centre for Development and Enterprise, 2017, p. 1). In addition, from a social market perspective, the right and responsibilities of a school democratic community (parents, teachers, learners, non-teaching staff, principal, and co-opted members) is defined as those of consumers of the commodity called education rather than those of participants in education. Also, teachers face difficulties in dealing with "socio-economic problems in the community, e.g. poverty and substance abuse" (Department of Education, 2015, p. 37). It is, I believe, fair to observe that if we find the contribution of NECC's concept of people's education as a vehicle for political mobilisation justifiable, we must also find neoliberal ideology, neoliberal governmentality, and neoliberal public policies untenable at best and unjustified at worst.

I want to argue one small, but significant point: protest scholars understand the adage that history can only be understood backwards but it must be lived forwards. Concurring with this view, Mbanjwa declared that "we are our history" (2014, p. 199). For the protest scholars human rights is always a creature of its past, but, also, a creature of its future. They see a logical relationship between stands taken on human rights and people's struggles. The protest scholars' refusal to take ahistorical and apolitical stances (sending the poor, unprivileged, and oppressed "back to the caves") to use Fanon's (1968, p. 183), expression, is supported by numerous pieces of legislation on human rights and education curriculum policy documents in post-apartheid South Africa. As Liebenberg has demonstrated, our "Constitution is simultaneously backward- and forward-looking" (2010, p. 25). The preamble of the Constitution of the Republic of South Africa "recognises the injustices of our past . . . so as to ... heal the divisions of the past and establish a society based on democratic values, social 
justice and fundamental human rights" (1996, p. 1). Equally important, the preamble of the South African Schools Act states that "the achievement of democracy in South Africa .. . requires a new national system for schools which will redress past injustices in educational provision, [and] provide an education of progressively high quality for all learners" (1996, p. 1).

Along these lines, the principles of CAPS are, inter alia, meant to transform South African society and promote human rights "to . . . ensur[e] that the educational imbalances of the past are redressed, and that equal educational opportunities are provided for all sections of our population ... [and to promote] social justice ... as defined in the Constitution of the Republic of South Africa" (2012, p. 3). Human rights legislation and education curriculum policy need to be commended for proclaiming learners' entitlement to social and economic rights. Most laudable is the attempt to transform and establish a society based on democratic values, social justice, and fundamental human rights. As the human rights framework tries to make its mark, however, the fundamental difficulties in realising the right to (high quality) education since the transition in 1994, is, arguably, yet to be achieved. One hopeful note is that we can draw inspiration from our history of triumphant struggle to reclaim the right to education that South Africans "fought for, won, lost, and [will win] again," to use Christie's (2010, p. 6) words yet again. Furthermore, to reinvigorate "people's power to advance people's agenda" (Rutledge, 2017, p. 1), South Africans should also take the word protest [invoking socio-economic rights as an integral part in the process to transformation, reconstruction and development] in the active, not passive, sense.

The phrase that human rights are people's struggle gives voice to local protesters to curtail the impact of neoliberal ideology, governmentality, and public policies that repress and attack individual liberty in post-apartheid South African schools. Boyte (2005) argues that there is a re-emergence of civic agency, i.e. of social movement struggles for equal rights and social and economic justice for "those experiencing continued oppression" (Suttner, 2015, p. 74). Without doubt, retrieving the gains of 1994 starts with protests for those denied their justiciable right to education by neoliberal ideology, governmentality, and policies in postapartheid South African schools. If one thinks in these terms, "it is within the intersection of (non)existing rights that all South African should assume common responsibility, dissolve the illusion and structure political spaces by insisting on the full realisation of the right to education" (Becker \& du Preez, 2016, p. 72). As Freire said, "the prophets are those that submerge themselves in the waters of their . . history and the history of the oppressed ... prophets know their 'here' and 'now' and . . . they can not only foresee the future, but they can realise it" (1970, cited in Torres, 2009, p. 94).

Only a return to a source, i.e. the struggle to reclaim our lost right to education as envisioned in the NECC and its concept of people's education as reflected in the Constitution of the Republic of South Africa (1996) can liberate educable learners from the bondage of neoliberal state ideology, governance, and policies. Margetson (1978) asserts that "participation together with democracy and education forms a three-piece suit (p. 35) . . [p]articipation is educative in that it is itself a learning process with the crucially valuable 
function of developing what is essentially human about persons" (p. 40). After all, neoliberalism as theory of political economic practices is "radically inconsistent with the defence of human rights, if human rights are perceived in relation to suffering rather than as abstract ground rules governing the relations of individuals to the State" (Spreen \& Vally, 2006, p. $353)$.

\section{Conclusion}

The concept of human right has undergone a transition from the beliefs of natural scholars, via deliberative scholars, to protest scholars. It is through the social contract theory that human beings recognise and reaffirm the status of socioeconomic rights as justiciable rights in modern democratic societies. Unfortunately, these socioeconomic rights are undermined by the neoliberal state education agenda's influence on global education system(s), education discourse, education budgets, formal and hidden curricula, and educational relations. In postapartheid South Africa, national legislation, education policy, and curriculum development make provision for education as a basic human right. But, in a different guise, the right to education lends impetus to the social market ideology, governance, and policies in schools. Neoliberal state education sits uneasily with the right to education but fits easily with the ideals of competitive elitism. As things stand, South Africa's democracy that guarantees fundamental rights and access to education for the elites is not best suited for demos, the "poor, the unprivileged and the oppressed" to borrow Dembour's (2010, p. 3) words. As democrats, we should take a leaf from protest scholars' conception of human rights to mean eternal vigilance, true and genuine human rights in post-apartheid South Africa. More importantly, human rights claims remain our political, philosophical, and collective struggle for equal education that liberates rather than domesticating those less fortunate than others.

\section{References}

Allais, S. (2014). Selling out education: National qualifications frameworks and the neglect of knowledge. Rotterdam, Netherlands: Sense.

Bassett, C. (2008). The South African people's budget campaign to neoliberal policy framework and methodology. In J. Mensah (Ed.), Neoliberalism and globalisation in Africa: Contestations on the embattled continent (pp. 221-239). New York, NY: Palgrave Macmillan.

Becker, A., \& du Preez, P. (2016). Ideological illusions, human rights and the right to education: The in(ex)clusion of the poor in post-apartheid education. Journal of Education, 64, 55-78.

Berlin I. (1969). Four essays on liberty. Oxford, UK: Oxford University Press.

Boyte, H. (2005). Free spaces, service learning and democratic politics. Los Angeles, CA: Service Learning Conference. 
Centre for Development and Enterprise (CDE). (2017). Teacher professional standards for South Africa: The road to better performance, development and accountability? Johannesburg, South Africa: CDE.

Chisholm, L., \& Fuller, B. (1996). Remembering people's education? Shifting alliances, state-building and South Africa's narrowing policy agenda. Journal of Education Policy, 11(6), 693-716.

Christie, P. (1988). The right to learn: The struggle for education in South Africa. Johannesburg, South Africa: Ravan Press.

Christie, P. (2008). Changing schools in South Africa: Opening the doors of learning. Johannesburg, South Africa: Heinemann.

Christie, P. (2010). The complexity of human rights in global times: The case of the right to education in South Africa. International Journal of Educational Development, 30(1), $3-11$.

Davids, M. N. (2016). A history of selected education systems. In K. Horsthemke, P. Siyakwazi, E. Walton, \& C. Wolhuter (Eds.), Education studies: History, sociology, philosophy (2nd ed., pp. 57-99). Cape Town, South Africa: Oxford University Press.

Dembour, M. B. (2010). What are human rights? Four schools of thought. Human Rights Quarterly, 32(1), 1-21.

Department of Education. (1996). South African Schools Act. Pretoria, South Africa: Government Printers.

Department of Education. (2012). Curriculum and assessment policy statement. Pretoria, South Africa: Government Printers.

Department of Education. (2015). Action plan to 2019 towards the realisation of schooling 2030: Taking forward South Africa's national development plan 2013. Pretoria, South Africa: Government Printers.

Enslin, P., \& Horsthemke, K. (2016). Philosophy of education: Becoming less western, more African? Journal of Philosophy of Education, 50(20), 77-190.

Fanon, F. (1968). The wretched of the earth (C. Farrington, Trans.). New York, NY: Grove Weidenfeld.

Grotius, H. (2005). The rights of war and peace. Indianapolis, IN: Liberty Fund. (Original work published 1620)

Gutmann, A. (1987). Democratic education. Princeton, NJ: Princeton University Press. 
Hanson, M., \& Hentz, J. J. (1999). Neocolonialism and neoliberalism in South Africa and Zambia. Political Science Quarterly, 144(3), 479-502.

Harris, A. (1997). The deprofessionalisation and deskilling of teachers. In K. Watson, K. Mogdil, \& S. Mogdil (Eds.), Education dilemmas: Debate and diversity - Teachers, teacher education and training (pp. 57-65). London, UK: Cassell.

Harvey, D. (2007). A brief history of neoliberalism. Oxford, UK: Oxford University Press.

Hobbes, T. (1985). Leviathan. London, UK: Penguin Books. (Original work published 1651)

Horsthemke, K. (2016). Ethics and values in education. In K. Horsthemke, P. Siyakwazi, E. Walton, \& C. Wolhuter (Eds.), Education studies: History, sociology, philosophy (2nd ed.) (pp. 281-337). Cape Town, South Africa: Oxford University Press.

Hulme, R. \& Hulme, M. (2012). The policy context of citizenship education. In J. Arthur \& H. Cremin (Eds.), Debates in citizenship education (pp. 43-55). London, UK: Routledge.

Kant, I. (1969). Foundations of the metaphysics of morals (L. White Beck, Trans.). Indianapolis, IN: Bobbs-Merrill. (Original work published 1785)

Kelly, P., Dacombe, R., Farndon, J., Hodson, A. S., Johnson, J., Kishtainy, N., \& Weeks, M. (2013). The politics book. London, UK: Dorling Kindersley.

Le Roux, C. (2016). The history of education in South Africa. In K. Horsthemke, P. Siyakwazi, E. Walton, \& C. Wolhuter (Eds.), Education studies: History, sociology, philosophy (2nd ed., pp. 2-41). Cape Town, South Africa: Oxford University Press.

Lewis, S. G., \& Motala, S. (2004). Educational de/centralisation and the quest for equity, democracy and quality. In L. Chisholm (Ed.), Changing class: Education and social change in post-apartheid South Africa (pp. 115-141). Cape Town, South Africa: Human Sciences Research Council.

Liebenberg, S. (2010). Socio-Economic rights: Adjudication under a transformative constitution. Cape Town, South Africa: Juta.

Locke, J. (1960). Two treaties of government. Cambridge, UK: Cambridge University Press. (Original work published 1689)

Margetson, D. (1978). Participation, democracy and education. Perspectives in Education, $3(1), 35-41$.

Mbanjwa, N. (2014). Simple expectations, complex transitions: The story of two decades of democracy. In B. Ngcaweni (Ed.), Liberation diaries: Reflections on 20 years of democracy (pp. 199-204). Johannesburg, South Africa: Jacana. 
Mensah, J. (2008). Neoliberalism and globalisation in Africa. In J. Mensah (Ed.), Neoliberalism and globalisation in Africa: Contestations on the embattled continent (pp. 1-14). New York, NY: Palgrave Macmillan.

Molteno, F. (1991). The historical foundations of the schooling of black South Africans. In P. Kallaway, (Ed.), Apartheid and education (pp. 45-107). Johannesburg, South Africa: Ravan Press.

Motala, S., \& Vally, S. (2002). People's education: From people's power to Tirisano. In P. Kallaway (Ed.), The history of education under apartheid, 1948-1994 (pp. 174-194). Cape Town, South Africa: Maskew Miller Longman.

Motala, S., \& Vally, S. (2014). Education, economy and society. Pretoria, South Africa: University of South Africa Press.

Nkomo, M. (1990). Pedagogy of domination: Toward a democratic education in South Africa. Trenton, NJ: Africa World Press.

Organisation of African Unity (OAU). (1986). African charter on human rights and people's rights. Nairobi, Kenya: OAU.

Organisation of African Unity (OAU). (1999). African charter on the rights and welfare of the child. Addis Ababa, Ethiopia: OAU.

Prinsloo, P. (2003). The quest for relevance: Preliminary thoughts on the issue of relevance in higher education in South Africa. Progressio, 25(1), 61-75.

Raphael, D. D. (1990). Problems of political philosophy (2nd ed.). London, UK: Macmillan.

Rawls, J. (1971). A theory of justice. Cambridge, MA: Belknap Press of Harvard University Press.

Republic of South Africa. (1996). The Constitution. Pretoria, South Africa: Government Printers.

Runes, D. D. (1960). Dictionary of philsophy: Ancient medieval-modern. Ames, IA: Littlefield, Adams \& Co.

Rutledge, C. (2017, July 23). For the elite, by the elite. City Press, p.1.

Sartre, J. P. (1974). Being and nothingness: An essay in phenomenological ontology. New York, NY: Citadel Press.

Scruton, R. (2007). Dictionary of political thought. Hampshire, UK: Palgrave Macmillan.

Sewpaul, V. (2014). Emancipatory education: Towards engaged citizenship, democratic practices and active community engagement. In L. Dominelli, \& M. Moosa-Mitha 
(Eds.), Reconfiguring citizenship: Social exclusion and diversity within inclusive citizenship practices (pp. 241-249). Farnham, UK: Ashgate.

Sisulu, Z. (1986). Keynote address: People's education for people's power. Transformation, $1,96-117$.

Smit, M. H. (2013). Fundamentals of human rights and democracy in education: A South African perspective. Pretoria, South Africa: van Schaik.

Spreen, C. A., \& Vally, S. (2006). Education rights, education policies and inequality in South Africa. International Journal of Educational Development, 26(4), 353-362.

Steger, M., \& Roy, R. K. (2010). Neoliberalism: A very short introduction. Oxford, UK: Oxford University Press.

Suttner, R. (2015). Recovering democracy in South Africa. Johannesburg, South Africa: Jacana.

Torres, C. A. (2009). Education and neoliberal globalisation. New York, NY: Taylor \& Francis.

United Nations. (1948). Universal declaration of human rights. New York, NY: United Nations.

United Nations. (1989). Convention on the rights of the child. New York, NY: United Nations.

Waghid, Y. (2005). Action as an educational virtue: Towards a different understanding of democratic citizenship education. Educational Theory, 55(3), 331-342.

Wolff, J. (1996). An introduction to political philosophy. Oxford, UK: Oxford University Press.

Vally, S. (2007). From people's education to neo-liberalism in South Africa. Review of African Political Economy, 34(111), 39-56.

Van den Berg, O. (1987, February). People's education: Its context, essence and (possible) direction. Paper presented at the Second Southern African Educational Conference of the Institute for Reformational Studies, Potchefstroom University for CHE, South Africa. 